\title{
IAMJ
}

INTERNATIONAL

AYURVEDIC

MEDICAL JOURNAL

Review Article

ISSN: 2320-5091

Impact Factor: 6.719

\section{A REVIEW ARTICLE - CONCEPT OF OLIGOMNIOSIS IN AYURVEDA}

\author{
Geetha Kumar ${ }^{1}$, Indusree C Suseelan ${ }^{2}$ \\ ${ }^{1}$ Associate Professor Department of Rachana Shareera, \\ ${ }^{2}$ Assistant Professor, Department of Rachana Shareera, \\ Sri Jayendra Saraswathi Ayurveda College \& Hospital, Nazarethpet, Chennai, Tamil Nadu, India
}

Corresponding Author: drindusree@sjsach.org.in

https://doi.org/10.46607/iamj1509052021

(Published Online: May 2021)

Open Access

(C) International Ayurvedic Medical Journal, India 2021

Article Received: 22/04/2021 - Peer Reviewed: 04/05/2021 - Accepted for Publication: 11/05/2021

Check for updates

\begin{abstract}
Introduction: The recent incidences of oligoamnios according to the prospective case control study $23 \%$ prevale nce among the three hundred eight antenatal ladies with singleton pregnancy between 34 and 41 weeks of gestatio $\mathrm{n}$ included in the study. The relevance of understanding oligoamnios from an Ayurvedic perceptive is the main co ntent. Aim and Objective: To understand the condition of Oligoamnios under the Ayurvedic perspective and to $r$ eview the Ayurvedic classics and critically analyses the same. Materials \& Methods: All Ayurvedic classic text authored by Brihatrayees and Laghutrayees, related journals, modern biomedical text and web were referred for $r$ eview of literature. Literature Review: Oligoamniosis is characterized by less volume of liquor amnii (less than 2 $00 \mathrm{ml}$ at $20-41^{\text {st }}$ weeks of gestation), affecting the well-being and maturity of the growing fetus. The lubricating ac tion of liquor amnii is reduced, the free movements of the fetus affected and cause adhesion between the body part s and with the amniotic sac can be seen as complications. Discussion: Ayurvedic point of view oligo-hydramnios can be considered under the broad spectrum of jarayu dosha mentioned in Sarangadhara Samhitha. According to Acharya Sarangadhara, jarayu is the membranous covering of the fetus in its intra-uterine life while the liquor amnii secreted from amnion as ambu/garbhodaka. Conclusion: From an Ayurveda viewpoint, oligoamnios can b e considered under the broad spectrum of ambupoornavyadhi or ulbakaroga characterized by hridroga (cardiac di sorder), akshepaka (convulsions), swasa (dysnoea), kasa (cough), chardi (vomiting) and jwara (fever) etc., disord ers and also all abnormalities of amnion such as unusual friability, amnionitis, cyst, amnion nodosum, amniotic ad hesions along with poly-hydramnios and oligo-hydramnios.
\end{abstract}


Keywords: oligo-hydramnios, amnion, Ambu, garbhodaka, Jarayudosha

\section{INTRODUCTION}

The incidence of oligoamniosisas per a prospective ca se control study undertaken in Maharajah's Institute of Medical Sciences, Vizianagaram, A.P, over a period of 2 years reports about the impact of oligoamnios on perinatal outcome. Among the Three hundred eight an tenatal ladies with singleton pregnancy between 34 an d 41 weeks of gestation included in the study, the inci dence of oligoamnios is $23 \%$ which is high comparin $\mathrm{g}$ to many studies ${ }^{1}$. Oligoamniosis characterized by le ss volume of liquor amnii (less than $200 \mathrm{ml}$ at $20-41^{\text {st }} \mathrm{W}$ eeks of gestation), affecting the well-being and maturi ty of the growing fetus. Since lubricating action of liq uor amnii reduced, the free movements of the fetus aff ected and cause adhesion between the body parts and with the amniotic sac can be seen as complications.

In Ayurvedic point of view oligo-hydramnios can be c onsidered under the broad spectrum of jarayu dosha mentioned in Sarangadhara Samhitha ${ }^{2}$.According to Acharya Sarangadhara jarayu is the membranous cov ering of the fetus in its intra-uterine life $^{3}$. The liquor a mnii secreted from amnion can be considered as ambu / garbhodaka ${ }^{4}$ Any abnormality of jarayu includes all abnormalities of amnion that means unusual friability, amnionitis, cyst, amnionnodosum, amniotic adhesion $\mathrm{s}$ along with poly-hydramnios and oligo-hydramnios $\mathrm{c}$ an be included ${ }^{5}$

\section{Aim \& Objective:}

- Tounderst and the condition of Oligoamnios under the Ayurvedic perspective

- To review the Ayurvedic classics and critically analyses the same.

\section{Materials \& Methods:}

All Ayurvedic classic text authored by Brihatrayees an $\mathrm{d}$ Laghutrayees, related journals, modern biomedical $\mathrm{t}$ ext and web were referred for review of literature.

\section{Review of Literature}

\section{Ayurveda Review:}

In Ayurvedic viewpoint, oligo-hydramnios can be con sidered under the broad spectrum of jarayudoshament ionedin Sarangadhara Samhitha ${ }^{6}$.
According to Acharya Sarangadhara jarayu is the me mbranous covering of the fetus in its intra uterine life similarto amnion. In view of the Jarayuutpatti (origin of amnion), Acharya Vagbhata mentions that there is obstruction of the openings of arthavavahasrotas are a fter conception. Due to this very reason the arthava ( menstruation) is

not seen after conception. Later this very arthava goes upward and gets accumulated, to form structure know $\mathrm{n}$ as Apara, or Jarayu according to some scholars ${ }^{7}$.

Acharya Dalhana quoting the passage of Acharya Bho ja mentions that origin of the placenta is from rakta (b lood, and the umbilical cord of fetus is from rasa (esse nce of food) ${ }^{8}$.

Acharya Indu opines that besides the accumulation of arthava, the diet used by mother also plays a role in gradual formation of Apara ${ }^{9}$.

While mentioning the garbhotpataka bhavas (factors essential for conception) Acharya Susrutha famously quotes the simile of equating process of germination $o$ $f$ seeds with achievement of conception. He states that if ritu (season or period near ovulation or ritukala), $b i$ ja (seed i.e. ovum and sperm), kshetra (irrigated field i .e. female reproductive system) and a $m b u$ (water i.e. $\mathrm{n}$ ourishing substances) assembled together, the concept ion will definitely occur ${ }^{10}$.Commenting on this Achar ya Dalhana referred Ambu as 'aharapaakauttpanna ra $s a$ ' (nourishment from essence of mother's diet) ${ }^{11}$.

Acharya Vagbhatahas used the term ambu/garbhodak ain context of ulbakaroga. Due to improper emesis of garbhodaka (liquor amnii) or because of contact of sle shma (mucous) situated in throat with the heart, the $r a$ saget vitiated and encircles or obstructs the marga(cha nnels)of pranavahasrotas (channel for vital energy). F urthermore, due to this, the fist of child gets tightened and he may suffer from diseases like hridroga (cardia c disorder), akshepaka (convulsions), swasa (dysnoea, kasa (cough), chardi (vomiting) and jwara (fever) et., disorders. This condition is known as ulbaka, sahajao rambupoornavyadhi. ${ }^{12}$ Also, according to the commen 
tary, the liquor amnii secreted from amnion can be co nsidered as this $a m b u^{13}$.

\section{JarayuDosha}

The termed jarayudosha as mentioned by Acharya Sar angadhara referring to the abnormalities of jarayu ${ }^{14}$. This includes spectrum of all abnormalities of amnion such as unusual friability, amnionitis, cyst, amnion no dosum, amniotic adhesions along with poly-hydramni os and oligo-hydramnios ${ }^{15}$.

\section{Modern Review:}

Amnion is the inner layer of the fetal membrane; its in ternal surface is smooth and shiny and is in contact wi th liquor amnii. The outer surface consists of layer of connective tissue. The amnion can be peeled off from the fetal surface of the placenta except at the insertion of the umbilical cord ${ }^{16}$.
Structure of amnion

Fully formed amnion is $0.02-0.5 \mathrm{~mm}$ in thickness and from within outwards the layers are

1) Single layer of cuboidal epithelium

2) Basement membrane

3) Compact layer of reticular structure

4) Fibroblastic layer and

5) Spongy layer

The Amniotic fluid accumulates slowly at first, but ult imately the fluid filled cavity becomes larger enough $\mathrm{t}$ o obliterate the chorionic cavity, the amnion and chori on come in loose contact by their mesenchymal layers. Initially the cavity is located on the dorsal surface of $t$ he embryonic disc ${ }^{17}$

Table 1: Formation and circulation of amniotic fluid ${ }^{18}$

\begin{tabular}{|c|c|}
\hline Formation & Removal \\
\hline $\begin{array}{l}\text { - Transudation of maternal serum across the placental membrane } \\
\text { - Transudation from fetal circulation across the umbilical cord or } \\
\text { placental membranes } \\
\text { - Secretion from amniotic epithelium } \\
\text { - Transudation of fetal plasma through the highly permeable fetal } \\
\text { - } \text { skin before it I s keratinized at } 20^{\text {th }} \text { week } \\
\text { - } \quad \text { Fetal lung fluid that enters the amniotic cavity to add to its volume }\end{array}$ & $\begin{array}{l}\text { Fetus swallows about } 400-700 \mathrm{ml} \text { of liquor } \\
\text { every day } \\
\text { Intra-membranous absorption of water and } \\
\text { solutes ( } 200-500 \mathrm{ml} \text { per day) from the amni- } \\
\text { otic compartment to fetal circulation through } \\
\text { the fetal surface of the placenta. }\end{array}$ \\
\hline
\end{tabular}

The amnion has got neither neuro-vascular supply nor any lymphatic drainage

Table 2: Features of amniotic fluid: ${ }^{20}$

\begin{tabular}{|c|c|c|c|}
\hline Origin of Amniotic Fluid: & Circulation: & Physical Features: & Color: \\
\hline $\begin{array}{l}\text { The precise origin of the liq } \\
\text { uor amnii still not well unde } \\
\text { rstood. It is probably of mix } \\
\text { ed maternal and fetal origin. }\end{array}$ & $\begin{array}{l}\text { The water in the amniotic fluid } \\
\text { is completely changed and rep } \\
\text { laced in every } 3 \text { hours as show } \\
\mathrm{n} \text { by the clearance of radioacti } \\
\text { ve sodium injected directly int } \\
\text { o the amniotic cavity. The pres } \\
\text { ence of lanugo and the fluid is } \\
\text { faintly alkaline with low specif } \\
\text { ic gravity of } 1.010 \text {. It becomes } \\
\text { highly hypotonic to maternal s } \\
\text { erum at term pregnancy. An os } \\
\text { molarity of } 250 \text { m Osmol/litre } \\
\text { is suggestive In early pregnanc } \\
\text { y it is colorless but near term it }\end{array}$ & $\begin{array}{l}\text { of fetal maturity. The amniotic } \\
\text { fluid's osmolarity falls with a } \\
\text { dvancing gestation. }\end{array}$ & $\begin{array}{l}\text { from the fetal skin. It } \mathrm{m} \\
\text { ay look turbid due to th } \\
\text { e presence of vernix ca } \\
\text { seosa. }\end{array}$ \\
\hline
\end{tabular}




\begin{abstract}
becomes pale, straw colored $\mathrm{d}$ ue to the presence of exfoliate $\mathrm{d}$ lanugo and epidermal cells epithelial scales in the meconi um shows that the fluid is swal lowed by the fetus and some of it passes from the gut into the fetal plasma.
\end{abstract}

ABNORMAL COLOR: Deviation of the normal color of the liquor has got clinical significance.

Meconium stained (green) is suggestive of fetal distress in presentations other than the breech or transverse. Depending upon the degree and duration of distress, it may be thin or thick or pea-souped (thick with flakes). Thick with presences of flakes suggest chronic fetal distress.

Golden color in Rh incompatibility is due to excessive heamolysis of the fetus RBC and production of excess bilirubin. Greenish-yellow (saffron) in post-maturity.

Dark colored in concealed accidental hemorrhage is due to contamination of blood.

Dark brown (tobacco juice) amniotic fluid is found in IUD. The dark color is due to frequent presences of old $\mathrm{HbA}$ VOLUME: Amniotic fluid volume is related to gestational age. It measures about

\section{Volume}

$50 \mathrm{ml}$

$400 \mathrm{ml}$

1 liter

\section{Gestational age}

12 weeks

20 weeks

36-38 weeks

Thereafter the amount diminutions about $600-800 \mathrm{mlat}$ term. As the pregnancy continues post term, further reduction occur s to the extent of about $200 \mathrm{ml}$ at 43 weeks.

COMPOSITION: The first half of pregnancy, the composition of the fluid is almost identical to a transudate of plasma. B ut in late pregnancy the composition very much altered mainly due to contamination of fetal urinary metabolites. The com position includes:- Water (98-99\%) and Solid (1-2\%). The solid part includes organic, inorganic and few suspended partic les.

\begin{tabular}{|c|c|}
\hline Organic & Inorganic \\
\hline Protein $(0.3 \%)$ & \multirow{7}{*}{$\begin{array}{l}\text { The concentration of sodium, chloride an } \\
\mathrm{d} \text { potassium is almost the same as that fo } \\
\text { und in maternal blood. As pregnancy adv } \\
\text { ances there may be slight fall in the sodiu } \\
\mathrm{m} \text { and chloride concentration probably c } \\
\text { ue to dilution by hypotonic fetal urine. W } \\
\text { hereas the potassium concentration rema } \\
\text { ns Include lanugo, exfoliated squamous } \\
\text { pithelial cells from the fetal skin, vernix } \\
\text { aseosa, cast of amniotic cells and cells fi } \\
\text { om the respiratory tract, urinary bladder a } \\
\text { nd vagina of the fetus }\end{array}$} \\
\hline Glucose (20 mg) & \\
\hline Urea (30mg) & \\
\hline NPN (30mg) & \\
\hline Uric acid (4mg) & \\
\hline Creatinine $(2 \mathrm{mg})$ & \\
\hline Total lipids (50mgs) & \\
\hline
\end{tabular}

\section{Suspended Particles}

unaltered

FUNCTION: its main function is to protect the fetus.

\title{
During pregnancy \\ During labor
}

It acts as a shock absorber, protecting the fetus from possible extraneous injury,

Maintains an even temperature

The fluid distance amniotic sag and thereby allows for grow and free

The amnion and chorion are combined to form a hydrostatic wedge which helps in dilatation of cervix.

During uterine contractions it prevents marked 
movements of the fetus and prevents adhesion between the fetal parts and amniotic sag.

Its nutritive value is negligible because of small amounts of protein and salt content. However, water supply to the fetus is quite adequate. interference with the placental circulations so long as the membranes remain intact.

It flushes birth canal at the end of the $1^{\text {st }}$ stage of labor and by its aseptic and bactericidal action protects the fetus and prevents ascending infections to the urinary cavity.
Excess or less volume of liquor amnii is assessed by A FI (amniotic fluid index). Maternal abdomen is divide $\mathrm{d}$ into quadrants taking the umbilicus, symphysis pubi $\mathrm{s}$ and the fundus as the reference points. With ultra-so und the largest vertical pocket in each quadrant is mea sured.
The sum of the 4 measurements $(\mathrm{cm})$ is the AFI. It is measured

to diagnose the clinical condition of poly-hydramnios and oligo-hydramnios respectively ${ }^{22}$.

Table 3: Clinical Importances ${ }^{21}$

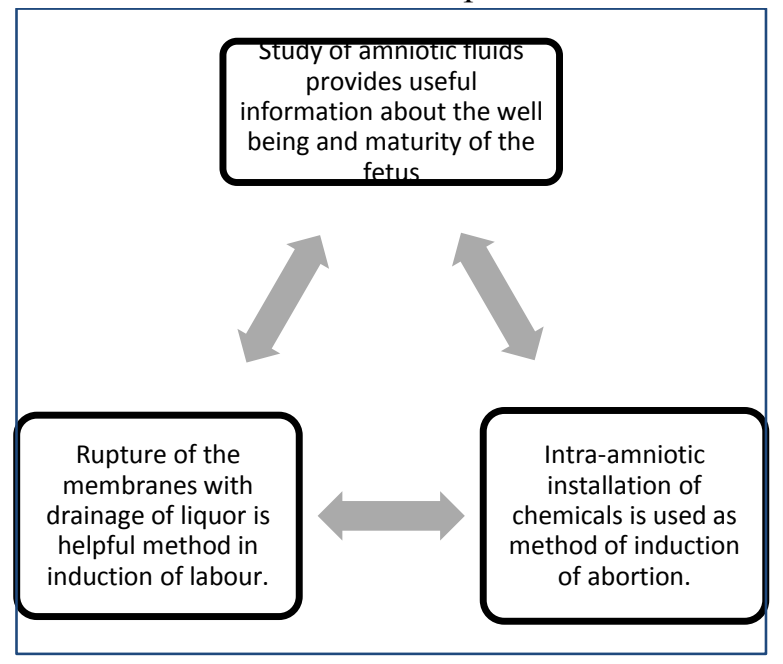

\section{DISCUSSION}

Oligoamniosis is characterized by less volume of liqu or amnii (less than $200 \mathrm{ml}$ at $20^{\text {th }}-41^{\text {st }}$ weeks of gestatio $\mathrm{n}$ ), affecting the well-being and maturity of the growin $\mathrm{g}$ fetus. Also, the lubricating action of liquor amnii wil 1 be reduced, affecting the free movements of the fetus and causing adhesion between the body parts and wit $\mathrm{h}$ the amniotic

sac. In a prospective case control study undertaken ov er a period of 2 years the incidence of oligoamniosis s hows about the $23 \%$ impact among the 380 antenatal ladies with singleton pregnancy between 34 and 41 we eks of gestation included in the study.

The amniotic fluid provides support for the delicate tis sue of the growing embryo or fetus. It allows free mov ement and protects the fetus from external injury. It al so avoids adhesion of the fetus to amnion. As the preg nancy advances, the quantity of this fluid increases till at full term it is about 1 litre. The condition in which $t$ here is too much amniotic fluid over $1500 \mathrm{ml}$ is called hydramnios. When the fluid is too little it is called Oli goamnios. Both conditions can cause abnormalities in the fetus. They can also cause difficulties during child birth. There is constant exchange of water between the amniotic fluid and maternal blood, the water been co mpletely replaced every three hours. Sometimes in the fifth month the fetus begins to swallow amniotic fluid . This fluid is absorbed (through the gut) into fetal blo od and it is transferred through the placenta to materna 1 blood. When the fetal kidneys start working the fetus passes urine into the amniotic fluid. This does not cau se harm because fetal urine is made up of mostly of w 
ater (metabolic waste been removed from blood by the placenta and through the kidneys) ${ }^{23}$. In some cases, $h$ ydramnios is associated with atresia of the esophagus, which prevents swallowing of amniotic fluid by the fe tus. Oligoamnios sometimes associated with renal age nesis as no urine is added to the amniotic fluid ${ }^{24}$.

During the formation of germ layers, a cavity appears on the between the ectoderm and the trophoblast i.e. a mniotic cavity filled by amniotic fluid or liquor amnii. The roof of the cavity is formed by amniogenic cells derived from the trophoblast while its floor is derived from the ectoderm ${ }^{25}$.

In Ayurvedic perceptive oligo-hydramnios can be con sidered under the broad spectrum of jarayudosha ment ioned in Sarangadhara Samhitha. According to Achary a Sarangadhara jarayu is the membranous covering o $\mathrm{f}$ the fetus in its intra-uterine life and the liquor amnii secreted from amnion as ambu/garbhodaka. Any abn ormality of jarayu includes all abnormalities of amnio $\mathrm{n}$ that means unusual friability, amnionitis, cyst, amni on nodosum, amniotic adhesions along with poly-hydr amnios and oligo-hydramnios can be included.

In view of the Jarayuutpatti (origin of amnion), Achar ya Vagbhata mentions that there is obstruction of the $o$ penings of arthavavahasrotas are after conception res ulting in absence of arthava (outer flow) after concept ion. Later this very arthava goes upward and gets acc umulated, to form structure known as Apara, or Jaray $u$ as according to some other scholars.

As according to Acharya Dalhana and Acharya Bhojat he origin of the placenta is from rakta (blood), and the umbilical cord of fetus is from rasa (essence of food) Acharya Indu opines that besides the accumulation of arthava, the diet used by mother also plays a role in gr adual formation of Apara.

While mentioning the garbhotpataka bhavas (factors essential for conception) Acharya Susrutha famously quotes the simile of equating process of germination $o$ f seeds with achievement of conception. He states that if ritu, bija, kshetraand ambu, assembled together, the conception will definitely occur. Commenting on this Acharya Dalhana referred Ambu as 'aharapaakauttpa nna rasa' (nourishment from essence of mother's diet) . Acharya Vagbhata has used the term ambu/garbhod akain context of ulbakaroga. Due to improper emesis of garbhodaka (liquor amnii) or because of contact of sleshma (mucous) situated in throat with the heart, the rasa get vitiated and encircles or obstructs the marga (channels) of pranavahasrotas (channel for vital energ y). Also, according to the commentary, the liquor amn ii secreted from amnion can be considered as this $a m b$ $u$. Furthermore, due to this, the fist of child gets tighte ned and he may suffer from diseases like hridroga (ca rdiac disorder), akshepaka (convulsions), swasa (dysn oea), kasa (cough), chardi (vomiting) and jwara (feve r) etc., disorders. This condition is known as ulbaka, s ahajaorambupoornavyadhi.

The termed jarayudosha as mentioned by Acharya Sar angadhara referring to the abnormalities of jarayu. Thi $\mathrm{s}$ includes spectrum of all abnormalities of amnion suc $\mathrm{h}$ as unusual friability, amnionitis, cyst, amnion nodos um, amniotic adhesions along with poly-hydramnios a nd oligo-hydramnios.

\section{CONCLUSION:}

Jarayu can be considered as the membranous covering of the fetus in its intra-uterine life. Again, ambu or $g a$ rbhodaka derived from rakta (blood) and also from ' $a$ harapaakauttpanna rasa' can be considered as the liq uor amnii. The termed jarayudosha as mentioned by Acharya Sarangadhara referring to the abnormalities o f jarayu. This includes spectrum of ambupoornavyadh $i$ or ulbakaroga characterized byhridroga (cardiac dis order), akshepaka (convulsions), swasa (dysnoea), kas $a$ (cough), chardi (vomiting) and jwara (fever) etc., di sorders and also all abnormalities of amnion such as $u$ nusual friability, amnionitis, cyst, amnion nodosum, a mniotic adhesions along with poly-hydramnios and oli go-hydramnios.

\section{REFERENCES}

1. https://www.ncbi.nlm.nih.gov/pmc/articles/PMC53715 25/\#: :text=In\%20the \%20present $\% 20$ study $\% 2 \mathrm{C} \% 20$ in ci-

dence $\% 20$ of $\% 20$ oligoamnios $\% 20$ is $\% 2023 \% 20 \% 25 \% 2$ 0which, $4.2 \% 20 \% 25 \% 20$ of\%20group\%202\%20 women.

2. Acharya Sarangadhara, Sarangadhara Samhitha, 2010, Chaukhambha Sanskrit series office, Varanasi, pp-9798 
3. Prof. Premvati Tewari, Ayurvediyaprasuti tantra evamstriroga, part-1, Chaukhambha Orientalia, Varanasi, pp-379

4. Prof. Premvati Tewari, Ayurvediyaprasuti tantra evamstriroga, part-1, Chaukhambha Orientalia, Varanasi, pp-379

5. Prof. Premvati Tewari, Ayurvediyaprasuti tantra evamstriroga, part-1, Chaukhambha Orientalia, Varanasi, pp-379

6. Prof. Premvati Tewari, Ayurvediyaprasuti tantra evamstriroga, part-1, Chaukhambha Orientalia, Varanasi, pp-379

7. Prof. Premvati Tewari, Ayurvediyaprasuti tantra evamstriroga, part-1, Chaukhambha Orientalia, Varanasi, pp-141,142

8. Prof. Premvati Tewari, Ayurvediyaprasuti tantra evamstriroga, part-1, Chaukhambha Orientalia, Varanasi, pp-141,142

9. Prof. Premvati Tewari, Ayurvediyaprasuti tantra evamstriroga, part-1, Chaukhambha Orientalia, Varanasi, pp-141,142

10. Prof. Premvati Tewari, Ayurvediyaprasuti tantra evamstriroga, part-1, Chaukhambha Orientalia, Varanasi, pp-86, 87

11. Prof. Premvati Tewari, Ayurvediyaprasuti tantra evamstriroga, part-1, Chaukhambha Orientalia, Varanasi, pp-86, 87

12. Prof. Jyotir Mitra, Astangasamgraha with sasilekha Sanskrit commentary by Indu, edited by Dr Shivprasad Sharma, Chaukhambha Sanskrit series office, Varanasi, pp-648.

13. Prof. Premvati Tewari, Ayurvediyaprasuti tantra evamstriroga, part-1, chaukhamba Orientalia, Varanasi, pp-636

14. Prof. Premvati Tewari, Ayurvediyaprasuti tantra evamstriroga, part-1, Chaukhambha Orientalia, Varanasi, pp-387

15. Prof. Premvati Tewari, Ayurvediyaprasuti tantra evamstriroga, part-1, Chaukhambha Orientalia, Varanasi, pp-387

16. D C Dutta, Textbook of Obstetric, $7^{\text {th }}$ edition, edited by Hiralal Kumar, New Central Book agency (P) Ltd, London, pp-37

17. D C Dutta, Textbook of Obstetric, $7^{\text {th }}$ edition, edited by Hiralal Kumar, New Central Book agency (P) Ltd, London, pp-27

18. D C Dutta, Textbook of Obstetric, $7^{\text {th }}$ edition, edited by Hiralal Kumar, New Central Book agency (P) Ltd, London, pp-37
19. D C Dutta, Textbook of Obstetric, $7^{\text {th }}$ edition, edited by Hiralal Kumar, New Central Book agency (P) Ltd, London, pp-38

20. D C Dutta, Textbook of Obstetric, $7^{\text {th }}$ edition, edited by Hiralal Kumar, New Central Book agency (P) Ltd, London, pp-38-39

21. D C Dutta, Textbook of Obstetric, $7^{\text {th }}$ edition, edited by Hiralal Kumar, New Central Book agency (P) Ltd, London, pp-39

22. D C Dutta, Textbook of Obstetric, $7^{\text {th }}$ edition, edited by Hiralal Kumar, New Central Book agency (P) Ltd, London, pp-39

23. Inderbir Singh, G P. Pal, Human embryology, $8^{\text {th }}$ edition, Macmillan publication, pg 75

24. Inderbir Singh, G P. Pal, Human embryology, $8^{\text {th }}$ edition, Macmillan publication, pg 75

25. Inderbir Singh, G P. Pal, Human embryology, $8^{\text {th }}$ edition, Macmillan publication, pg 39

\section{Source of Support: Nil \\ Conflict of Interest: None Declared}

How to cite this URL: Geetha kumar \& Indusree C Suseelan: A Review Article - Concept Of Oligomniosis In Ayurveda. International Ayurvedic Medical Journal \{online\} 2021 \{cited May, 2021\} Available from: http://www.iamj.in/posts/images/upload/1037_1043.pdf 